\title{
PRESCRIPTION DRUG ABUSE AMONG COMMUNITY TRAFFIC CONTROL VOLUNTEERS IN MAKASSAR, SOUTH SULAWESI
}

\author{
Muhammad Syafar, Serly \\ Department of Health Promotion and Behavior Sciences, \\ Universitas Hasanuddin
}

\begin{abstract}
Background: Misuse of prescription drugs has increased among young adults in the Indonesia. Despite these upward trends, few studies have examined prescription drug misuse among community traffic controller volunteers. This study aimed to investigate prescription drug abuse among community traffic control volunteers in Makassar, South Sulawesi.

Subjects and Method: This was a qualitative study carried out in Makassar, South Sulawesi. A total of 7 traffic control volunteers namely Pak Ogah were selected for this study. The data were collected by in-depth interview, direct observation, and document review.

Results: Lack of knowledge, peers, easy to access, and weak regulations were factors associated with prescription drug abuse.

Conclusion: Social factors are the main reason for prescription drug abuse.
\end{abstract}

Keywords: abuse, prescription drugs, OTC drugs, Pak Ogah

Correspondence:

Muhammad Syafar. Department of Health Promotion and Behavior Sciences, Universitas Hasanuddin. Email: syafar.muhammad@yahoo.co.id.

The $5^{\text {th }}$ International Conference on Public Health

Best Western Premier Hotel, Solo, Indonesia, February 13-14, 2019 | 230

https://doi.org/10.26911/theicph.2019.02.48 